\title{
PENGEMBANGAN KINERJA GURU MELALUI PENELITIAN TINDAKAN KELAS PADA SMA NEGERI DI KOTA PALOPO
}

\author{
Hilal Muhammad \\ Fakultas Tarbiyah dan Keguruan IAIN Palopo \\ Jalan Agatis Balandai, Kota Palopo \\ Email: hilalmahmud_wero@yahoo.com \\ Muh. Yaumi \\ Fakultas Tarbiyah dan Keguruan UIN Alauddin Makassar \\ Kampus II: Jalan Sultan Alauddin Nomor 36 Samata- Gowa \\ Email: muhammadyaumi@yahoo.com
}

\begin{abstract}
Abstrak:
Tujuan penelitian ini adalah untuk mengungkap: (1) pelaksanaan pengembangan kinerja guru melalui PTK pada SMA Negeri di Kota Palopo; dan (2) hambatan dalam pelaksanaan pengembangan kinerja guru melalui PTK pada SMA Negeri di Kota Palopo. Jenis penelitian adalah penelitian lapangan yang kajiannya bersifat kualitatif-verifikatif. Pendekatan yang digunakan adalah pendekatan fenomenologi. Metode pengumpulan data yang digunakan dalam penelitian ini adalah wawancara, observasi, dan dokumentasi. Hasil penelitian ini menunjukkan dua hal. Pertama, pengembangan kinerja guru melalui PTK pada SMA Negeri di Kota Palopo belum berjalan optimal dan baru sebatas memenuhi kebutuhan persyaratan kenaikan pangkat. Potensi guru belum dimanfaatkan melalui pemberdayaan, khususnya penelitian tindakan kelas. Kedua, hambatan dalam pelaksanaan pengembangan kinerja guru melalui PTK pada SMA Negeri di Kota Palopo adalah keterbatasan waktu, dana, sumber referensi kurang, lingkungan tidak kondusif, dan motivasi kurang. Selain itu, sebagian guru juga masih mengalami kesulitan dalam melakukan dan menyusun laporan hasil PTK.
\end{abstract}

\begin{abstract}
:
The purpose of this study was to reveal: (1) the implementation of the teachers' performance development through action research at SMAN in Palopo; and (2) the obstacle of the implementation of the teachers' performance development through action research at SMAN in Palopo. This research included field research that was qualitative verification. The approach used was phenomenology. Data collection methods used in this research were interview, observation, and study documentation methods. The results of this research indicated two things. First, the implementation of the teachers' performance development through action research had not been made entirely optimal and it was just limited on the fulfillment of task demand in the prequisite of promotion. The teachers' potential had not been made entirely used optimally through empowerment, especially in action research. Secondly, the obstacle of the implementation of the teachers' performance development through action research at SMAN in Palopo were about the limitation of time and fund, lack of reference, not condusive atmosphere, and lack of motivation. Furthermore, some teachers still had difficulties in doing and writing the result of their action research.
\end{abstract}

Kata Kunci:

Kinerja Guru, Pengembangan, Penelitian Tindakan Kelas 
GURU sangat menentukan dan memiliki peranan yang sangat menentukan dalam upaya pembaharuan dan keberhasilan pendidikan. Studi Heyneman dan Loxley di 29 negara menemukan bahwa guru memberikan kontribusi terhadap prestasi belajar sebesar 34\% di 16 negara sedang berkembang (India, Mesir, Botswana, Thailand, Chili, El-Salvador, Kolombia, Meksiko, Brazil, Argentina, Peru, Uganda, Hongaria, Paraguay, Iran, Bolivia). Di 13 negara industri (Amerika Serikat, Inggeris, Skotlandia, Belanda, Jerman, Swedia, Belgia yang meliputi tiga kelompok etnis, Selandia Baru, Australia, Italia, Jepang) kontribusi guru terhadap mutu pendidikan adalah $36 \%$. ${ }^{1} \mathrm{Hal}$ tersebut menunjukkan bahwa peran guru dalam penyelenggaraan pendidikan sangat dominan terhadap pencapaian mutu pendidikan.

Dalam rangka meningkatkan kualitas pelaksanaan tugas guru untuk mendukung upaya peningkatan mutu pendidikan maka program pengembangan kinerja guru menjadi suatu keniscayaan. Namun berdasarkan fakta di lapangan, ditemukan kondisi bahwa pelaksanaan program pengembangan kinerja guru di sekolah masih belum optimal. Kondisi ini didasarkan pada beberapa fakta. Pertama, pada umumnya guru belum mendapatkan kesempatan memadai untuk mendapatkan bimbingan dan pendampingan melalui supervisi pembelajaran. Kedua, Musyawarah Guru Mata Pelajaran (MGMP) sebagai wadah tempat para guru mata pelajaran sejenis berkumpul, saling berbagi informasi, serta menjadi tempat guru meningkatkan dan mengembangkan kinerjanya, belum dimanfaatkan secara optimal. Ketiga, Penelitian Tindakan Kelas sebagai salah satu kegiatan pengembangan kinerja guru belum dilaksanakan secara optimal.

Persyaratan yang begitu tinggi dan ketat dalam pencapaian kategori sekolah yang memiliki keunggulan baik input, proses, maupun output sebagaimana dipersyaratkan sebagai sekolah masa depan, diperhadapkan dengan situasi dan kondisi faktual sekolah yang dikemukakan di atas yang masih dalam taraf "berjuang keras" untuk mengembangkan diri agar dapat mendekati persyaratan sekolah unggul masa depan. Situasi ini menarik dan menjadi isu mendasar yang berusaha diungkap untuk menjadi bahan kajian dan estimasi pola pengembangan kinerja guru yang lebih ideal bagi sekolah di kota Palopo, bahkan di Indonesia.

Salah satu pola pengembangan kinerja guru yang akan diungkap dalam penelitian ini adalah Penelitian Tindakan Kelas (PTK) dengan beberapa pertimbangan. Pertama, PTK merupakan salah satu aktivitas pengembangan kinerja guru yang memberdayakan. Kedua, PTK merupakan suatu pencermatan terhadap kegiatan belajar berupa sebuah tindakan yang sengaja dimunculkan dan terjadi dalam sebuah kelas secara bersama. Ketiga, PTK adalah kegiatan ilmiah sehingga laporan hasil PTK merupakan Karya Tulis Ilmiah (KTI) yang menjadi salah satu aspek pengembangan profesi guru.

Berdasarkan latar belakang yang telah diuraikan di atas maka masalah pokok yang akan dibahas dalam penelitian ini adalah bagaimana pengembangan kinerja guru melalui PTK pada SMA Negeri di Kota Palopo. Pokok masalah ini dirumuskan dalam beberapa sub masalah sebagai acuan pembahasan selanjutnya, yaitu: (1) bagaimana pelaksanaan pengembangan kinerja guru melalui PTK pada SMA Negeri di Ko- 
ta Palopo? dan (2) bagaimana hambatan dalam pelaksanaan pengembangan kinerja guru melalui PTK pada SMA Negeri di Kota Palopo? Hasil penelitian ini diharapkan dapat: (1) memberi kontribusi bagi organisasi sekolah dalam merancang dan melaksanakan model pengembangan kinerja guru; (2) sebagai bahan pertimbangan dalam memutuskan tindakan dan kebijakan program peningkatan mutu pendidikan yang mampu menumbuhkembangkan manajemen sekolah/madrasah yang kondusif menuju sekolah/madrasah masa depan; dan (2) Sebagai bahan pertimbangan dalam memutuskan tindakan program pengembangan kinerja guru yang mampu mengantisipasi perubahan.

\section{KAJIAN TEORETIS}

\section{Kinerja Guru dan Kepemimpinan Kepala Sekolah}

Kinerja merupakan terjemahan dari kata "performance" berarti pertunjukan, perbuatan, daya guna, hasil, prestasi, pelaksanaan. "Performance" berasal dari kata "to perform" berarti melakukan, menyelenggarakan, dan memainkan. ${ }^{2}$ Wibowo mengemukakan bahwa Armstrong dan Bacon memberikan arti "performance" sebagai kinerja, hasil kerja atau prestasi kerja. Kinerja adalah tentang apa yang dikerjakan dan bagaimana cara mengerjakannya. Kinerja juga merupakan hasil pekerjaan yang mempunyai hubungan kuat dengan tujuan strategis organisasi, kepuasan konsumen dan memberikan kontribusi ekonomi. ${ }^{3}$ Uhar Suharsaputra menyimpulkan bahwa kinerja merupakan suatu kemampuan kerja atau prestasi kerja yang diperlihatkan oleh seorang pegawai untuk memperoleh hasil kerja yang optimal. ${ }^{4}$ Dengan demikian, kinerja dapat dimaknai sebagai penampilan kerja atau prestasi kerja yang ditunjukkan seorang pegawai untuk memperoleh hasil kerja yang optimal sesuai dengan tujuan organisasi.

Kinerja dapat dipandang sebagai proses maupun hasil pekerjaan. Artinya, kinerja merupakan suatu proses tentang bagaimana pekerjaan berlangsung untuk mencapai hasil kerja. Namun, hasil pekerjaan itu sendiri juga menunjukkan kinerja. Wibowo mengemukakan bahwa faktor yang mendorong kinerja adalah perilaku, yaitu suatu cara seseorang bertindak atau melakukan. ${ }^{5}$ Kinerja yang efektif dalam pekerjaan adalah hasil dari melakukan sesuatu hal dengan cara yang benar pada waktu yang tepat atau cara yang benar untuk pekerjaan spesifik pada waktu yang spesifik. Tingkat kinerja yang dicapai tergantung pada tingkat seberapa perilakunya cocok dengan tuntutan perilaku dari pekerjaan. Perbaikan kinerja berkelanjutan membutuhkan perubahan perilaku yang didasarkan pada data yang dapat diamati dan diukur. Perubahan merupakan keputusan individu, suatu keputusan pimpinan. Perubahan organisasi dimulai dengan perubahan individu bagaimana mereka berperilaku dan memutuskan apa yang akan dilakukan. Merubah perilaku merupakan usaha yang sangat sulit. Faktanya, banyak orang menolak pandangan orang lain tentang apa yang sebaiknya dilakukan. Sebagian orang dapat menerima beberapa arahan, tetapi cenderung mengabaikan sebagian besar arahan atau tindakan yang disarankan. Untuk itu diperlukan pendekatan pribadi yang tepat. 
Robin Stuart-Kottze mengemukakan bahwa dalam realitas terdapat pula perilaku yang mempunyai konsekuensi negatif dan menurunkan kinerja, yaitu performance blocking behavior. Blocking behavior merupakan perilaku yang menghalangi perubahan, mengalahkan visi, dan merintangi pencapaian tujuan dan sasaran. Performance blocking behavior disebabkan oleh tekanan dan pengaruh eksternal, berupa ketidakpastian, kecemasan, tantangan, sikap meremehkan, kurangnya kekuasaan dan kontrol. ${ }^{6}$ Aspek yang kurang menguntungkan dari blocking behavior tidak hanya sekedar bahwa beberapa individu membuang waktu dan energi untuk melakukan hal yang kontra produktif, tetapi juga pengaruh negatif perilaku yang mereka miliki menular kepada orang lain. Untuk mengurangi pengaruh performance blocking behavior, cara terbaik adalah dengan mendapatkan umpan balik dari pekerja atau melalui kuesioner dan menyediakan cukup waktu dan usaha untuk menemukan akar masalah dan penyebabnya.

Kinerja guru adalah suatu kemampuan kerja dan prestasi kerja yang ditampilkan oleh guru dalam melaksanakan tugasnya. Pandangan ini sejalan dengan pandangan Supardi yang mengemukakan bahwa kinerja guru merupakan kemampuan dan keberhasilan guru dalam melaksanakan tugas-tugas pembelajaran. Supardi mengemukakan bahwa kinerja guru ditunjukkan oleh dimensi: (1) kemampuan menyusun rencana pembelajaran; (2) kemampuan melaksanakan pembelajaran; (3) kemampuan melaksanakan hubungan antar pribadi; (4) kemampuan melaksanakan penilaian hasil belajar; (5) kemampuan melaksanakan program pengayaan; dan (6) kemampuan melaksanakan program remedial. ${ }^{7}$ Kemampuan menyusun rencana pembelajaran dengan indikator: (a) merencanakan pengelolaan pembelajaran; (b) merencanakan pengorganisasian bahan pelajaran; (c) merencanakan pengelolaan kelas; (d) merencanakan penilaian hasil belajar. Kemampuan melaksanakan pembelajaran dengan indikator: (a) memulai pembelajaran; (b) mengelola pembelajaran; (c) mengorganisasikan pembelajaran; (d) melaksanakan penilaian proses dan hasil belajar; (e) mengakhiri pembelajaran. Kemampuan melaksanakan hubungan antar pribadi dengan indikator: (a) mengembangkan sikap positif peserta didik; (b) menampilkan kegairahan dalam pembelajaran; (c) mengelola interaksi perilaku dalam kelas. Kemampuan melaksanakan penilaian hasil belajar dengan indikator: (a) merencanakan penilaian; (b) melaksanakan penilaian; (c) mengelola dan memeriksa hasil penilaian; (d) memanfaatkan hasil penilaian; (e) melaporkan hasil penilaian. Kemampuan melaksanakan program pengayaan dengan indikator: (a) memberikan tugas; (b) memberikan bahan bacaan; (c) tugas membantu guru. Kemampuan melaksanakan program remedial dengan indikator: (a) memberikan bimbingan khusus; dan (b) penyederhanaan.

Direktorat Tenaga Kependidikan dalam Penilaian Kinerja Guru menyebutkan bahwa kinerja guru dapat dilihat dengan memperhatikan berbagai kemampuan yang ditampilkan dalam melaksanakan tugas-tugas pembelajaran. Tugas profesi guru mencakup: (1) rencana pembelajaran (teaching plans and materials) atau Rencana Pelaksanaan Pembelajaran (RPP); (2) prosedur pembelajaran (classroom procedure); dan (3) hubungan antar pribadi (interpersonal skill). ${ }^{8} \mathrm{Hal}$ ini sejalan dengan tugas guru yang 
disebutkan dalam Undang-Undang Republik Indonesia Nomor 14 Tahun 2005 tentang Guru dan Dosen, pasal 20 ayat b bahwa guru sebagai salah satu tenaga pendidik merupakan tenaga profesional yang bertugas merencanakan dan melaksanakan proses pembelajaran, menilai hasil pembelajaran, melakukan pembimbingan dan pelatihan, serta melakukan penelitian dan pengabdian kepada masyarakat, terutama bagi pendidik pada perguruan tinggi. Tentu saja, kemampuan yang dikemukakan di atas baru sebatas kemampuan yang ditampilkan guru dalam melaksanakan tugas-tugas pembelajaran. Kinerja guru sejatinya merujuk pada kompetensi guru (pedagogik, personal, sosial, dan professional) sebagaimana diatur dalam Undang-undang Republik Indonesia Nomor 19 Tahun 2005 tentang Standar Nasional Pendidikan.

Kinerja guru ditentukan oleh kompetensi, motivasi dan kepemimpinan kepala sekolah. Roland S. Barth dalam Suharsaputra menyatakan bahwa kepala sekolah merupakan kunci sekolah yang baik dan berkualitas, faktor potensial penentu iklim sekolah, serta sebagai pendorong bagi pertumbuhan para guru..$^{9}$ Kepala sekolah sebagai pimpinan suatu unit sekolah, disamping dipersyaratkan memiliki kualifikasi (umum dan khusus) berdasarkan Peraturan Menteri Pendidikan Nasional Republik Indonesia Nomor 13 Tahun 2007 tentang Standar Kepala Sekolah/Madrasah, juga dituntut memiliki kompetensi. Mulyasa memberikan definisi kompetensi sebagai perpaduan dari pengetahuan, keterampilan, nilai, sikap yang direpleksikan dalam kebiasaan bekerja dan bertindak. ${ }^{10}$ Dalam Peraturan Menteri Pendidikan Nasional Republik Indonesia Nomor 13 Tahun 2007 tentang Standar Kepala Sekolah/ Madrasah, terdapat lima kompetensi yang harus dimiliki oleh seorang kepala sekolah, yaitu kompetensi kepribadian, kompetensi manajerial, kompetensi kewirausahawan, kompetensi supervisi, dan kompetensi sosial. Kompetensi kepala sekolah merupakan kompetensi kepemimpinan yang menjadi dasar bagi keberhasilan sekolah dalam upaya mengembangkan kinerja inovatif guru.

Kebutuhan guru akan dorongan motivasi dan suasana kondusif untuk mewujudkan pembelajaran bermutu membutuhkan kepemimpinan kepala sekolah yang memiliki kemampuan mengembangkan setiap guru menjadi self-leader. Guru yang self leader adalah guru yang memiliki pola pikir, perilaku dan tanggungjawab mengatasi tantangan yang dibebankan kepadanya, inisiatif, kreatif, inovatif, dan mampu memimpin diri mereka sendiri. Kepala sekolah yang mampu mendesain, menetapkan sistem, memengaruhi, dan membentuk guru menjadi self-leader adalah superleader. Superleader adalah pemimpin yang mampu memimpin orang lain untuk memimpin diri sendiri. Superleader memungkinkan esensi semua kontrol atas kinerja guru adalah teristimewa pada kompetensi dan potensi guru itu sendiri, mendorong SDM guru untuk berinisiatif, bertanggungjawab sendiri, percaya diri, merencanakan tujuan sendiri, berpikir secara positif, dan mampu mengatasi permasalahan. ${ }^{11}$ Dalam upaya mengembangkan kinerja inovatif, para guru membutukan kepemimpinan kepala sekolah yang mememberi semangat untuk bertanggungjawab daripada memberi perintah. Kepala sekolah superleader diharapkan fokus pada strategi pemberdayaan melalui pe- 
ningkatan keterampilan, pengetahuan, dan keyakinan akan kemampuan dan potensi guru yang dipimpinnya.

\section{Pengembangan Kinerja Guru Melalui PTK}

Pengembangan merupakan salah satu prinsip dasar manajemen kinerja. ${ }^{12}$ Terdapat beberapa pandangan para pakar tentang pengembangan. R. Wayne Mondy dan Robert M. Noe memandang bahwa: "Development involves learning that goes beyond today's job and has a more long-term focus. It prepares employees to keep pace with the organization as it changes and grows". ${ }^{13}$ Pandangan Mondy dan Noe ini memberikan gambaran bahwa pengembangan merupakan pembelajaran atau upaya peningkatan pengetahuan yang dituntut dalam pekerjaannya dan fokus pada kepentingan jangka panjang. Pengembangan merupakan upaya mempersiapkan karyawan melaksanakan tugasnya pada organisasi atau lembaga yang senantiasa mengalami perubahan dan pertumbuhan.

Pandangan senada dikemukakan oleh Mangkuprawira bahwa pengembangan dapat diartikan berupa upaya meningkatkan pengetahuan yang mungkin digunakan segera atau sering untuk kepentingan di masa depan. ${ }^{14}$ Raymond A. Noe, dkk. Menjelaskan bahwa pengembangan mengacu pada pendidikan formal, pengalaman kerja, hubungan, penilaian kepribadian dan kemampuan yang membantu para karyawan mempersiapkan dirinya di masa depan. ${ }^{15}$ Dengan demikian, pengembangan merupakan kegiatan yang harus dilakukan oleh organisasi atau lembaga pendidikan agar pengetahuan, kemampuan, dan keterampilan karyawan/tenaga pendidik sesuai dengan tuntutan pekerjaan yang mereka lakukan. Dalam Kamus Besar Bahasa Indonesia 'kinerja' berarti sesuatu yang dicapai; prestasi yang diperlihatkan; atau kemampuan kerja. ${ }^{16}$ Amstrong dan Baron menjelaskan bahwa kinerja merupakan sarana untuk mendapatkan hasil yang lebih baik dari organisasi, tim, dan individu dengan cara memahami dan mengelola kinerja dakam kerangka tujuan dan standar, dan persyaratan atribut yang disepakati. ${ }^{17}$ Guru yang memiliki kinerja adalah guru yang memiliki kecakapan pembelajaran, wawasan keilmuan yang mantap, wawasan sosial yang luas, bersikap positif terhadap pekerjaannya, dan menunjukkan prestasi kerja sesuai standar kinerja yang dipersyaratkan. Kinerja guru merupakan kemampuan dan keberhasilan guru dalam melaksanakan tugas-tugas pembelajaran.

Merujuk pada pengertian pengembangan dan kinerja di atas maka pengembangan kinerja dapat diartikan sebagai prosedur kerja yang teratur dan sistematis yang dijadikan acuan dalam menjalankan yang dilakukan oleh organisasi atau lembaga pendidikan agar pengetahuan, kemampuan, dan keterampilan karyawan/tenaga pendidik sesuai dengan tuntutan pekerjaan mereka dalam menunjukkan kemampuan dan keberhasilan mereka melaksanakan tugas-tugas. Pengembangan kinerja guru merupakan prosedur kerja yang teratur dan sistematis yang dilakukan oleh organisasi atau lembaga pendidikan agar kompetensi tenaga pendidik sesuai dengan tuntutan tugas profesionalnya. Pengembangan kinerja guru dapat dilakukan melalui layanan supervisi pendidikan dan atau melalui Musyawarah Guru Mata Pelajaran (MGMP), dan Penelitian Tindakan Kelas (PTK). 
Penelitian Tindakan Kelas/Classroom Action Researh merupakan aktivitas yang merujuk kepada kajian yang dilakukan sendiri oleh guru melalui refleksi terhadap pembelajaran. Melalui PTK, guru secara individu atau dengan kerjasama dengan guru-guru lain melibatkan diri dalam penelitian tindakan kelas untuk memperbaiki mutu pembelajaran. PTK merupakan suatu pencermatan terhadap kegiatan belajar berupa sebuah tindakan yang sengaja dimunculkan dan terjadi dalam sebuah kelas secara bersama. PTK adalah kegiatan ilmiah sehingga laporan hasil PTK merupakan Karya Tulis Ilmiah (KTI) yang menjadi salah satu aspek pengembangan profesi guru.

Pengembangan kinerja guru melalui PTK merupakan upaya yang teratur dan sistematis yang dilakukan oleh guru dengan bantuan dan dukungan organisasi atau lembaga pendidikan agar kompetensi tenaga pendidik sesuai dengan tuntutan tugas profesionalnya. Pengembangan kinerja guru melalui PTK merupakan aktivitas pemberdayaan guru. Smith mengemukakan bahwa memberdayakan berarti mendorong orang menjadi lebih terlibat dalam keputusan dan aktivitas yang memengaruhi pekerjaan mereka. Robbins memberikan pengertian pemberdayaan sebagai menempatkan pekerja bertanggung jawab atas apa yang mereka kerjakan. Pandangan yang sama dengan formulasi berbeda dikemukakan oleh Greenberg dan Baron bahwa pemberdayaan merupakan suatu proses dimana pekerja diberi peningkatan sejumlah otonomi dan keleluasaan dalam hubungannya dengan pekerjaan mereka. Pandangan senada dikemukakan oleh Newdtrom dan Davis bahwa pemberdayaan merupakan setiap proses yang memberikan otonomi yang lebih besar kepada pekerja melalui saling menukar informasi yang relevan dan ketentuan tentang pengawaan atas faktor-faktor yang memengaruhi prestasi kerja. ${ }^{18}$ Sumber daya manusia yang diberdayakan diharapkan memiliki motivasi tinggi, kreatif, dan mampu mengembangkan inovasi sehingga kinerjanya akan semakin baik dan sempurna sesuai tujuan yang telah ditetapkan. Jika merujuk kepada pandangan tersebut di atas, maka pengembangan kinerja guru melalui PTK berarti pemberian kepercayaan, tanggung jawab, dan wewenang kepada guru agar lebih berdaya dan berkemampuan untuk menyelesaikan masalahnya sendiri melalui PTK. Dalam pengembangan kinerja guru melalui PTK, peran kepala sekolah sebagai pemimpin sangat penting. Kepala sekolah sebagai pemimpin harus senantiasa memberikan motivasi, menunjukkan empati, kepercayaan dan komitmen, serta menunjukkan hubungan kerja yang efektif.

\section{METODE PENELITIAN}

Penelitian ini termasuk jenis penelitian lapangan yang kajiannya bersifat kualitatif-verifikatif untuk mengungkap makna yang ada di balik fenomena realitas sosial tentang pengembangan kinerja guru melalui PTK pada SMA Negeri di Kota Palopo. Strategi analisis data dalam penelitian ini mengarah pada strategi analisis data kualitatif-verifikatif yaitu berupaya menganalisis data penelitian secara induktif yang dilakukan pada seluruh proses penelitian yang dilakukan. Untuk memahami fenomena-fenomena yang terjadi dalam pelaksanaan pengembangan kinerja guru melalui PTK pada SMA Negeri di Kota Palopo, peneliti bertolak dari data empiris yang di- 
temukan di lapangan. Penelitian ini juga tidak menetapkan penelitiannya berdasarkan variabel penelitian tetapi keseluruhan situasi sosial yang diteliti meliputi aspek tempat (place), yaitu SMA Negeri di Kota Palopo, pelaku (actor), yaitu para Kepala Sekolah, Pengawas Sekolah dan guru SMA Negeri di Kota Palopo, Komite Sekolah, serta Dewan Pendidikan Kota Palopo, dan aktivitas (activity), yaitu pelaksanaan pengembangan kinerja guru melalui penelitian tindakan kelas pada SMA Negeri di Kota Palopo. Pendekatan yang digunakan dalam penelitian ini adalah pendekatan fenomenologi dalam upaya memahami makna dari suatu peristiwa atau fenomena yang saling berpengaruh dengan pelaku dalam situasi tertentu dalam pengembangan kinerja guru melalui PTK pada SMA Negeri di Kota Palaopo. Dengan pendekatan fenomenologi, peneliti berupaya memahami fenomena-fenomena yang berkaitan dengan realitas, situasi, kondisi, dan interaksi yang terjadi dalam pelaksanaan pengembangan kinerja guru melalui PTK pada SMA Negeri di Kota Palopo.

Dalam penelitian ini peran peneliti adalah sebagai instrumen kunci dalam mengumpulkan data dengan menggunakan pengamatan langsung, wawancara, dan studi dokumen terhadap pelaksanaan pengembangan kinerja guru melalui PTK pada SMA Negeri di Kota Palopo. Pengamatan langsung dilakukan dengan cara mengamati guru, berusaha masuk di dalam dunia konseptual mereka dan berinteraksi dengan mereka di sekolah agar dapat memahami konstruksi berpikir mereka tentang pelaksanaan pengembangan kinerja guru melalui PTK yang mereka alami. Wawancara dilakukan dengan berusaha memahami, menggali pandangan dan pengalaman mereka untuk mendapatkan informasi atau data yang diperlukan. Data yang dikumpulkan dalam penelitian ini berupa data primer dan data sekunder. Data primer merupakan data yang diperoleh melalui kegiatan observasi, wawancara, dan dokumentasi. Data sekunder merupakan data yang diperoleh melalui studi dokumentasi berupa penelaahan dokumen pribadi/resmi, referensi, atau peraturan yang memiliki relevansi dengan fokus penelitian. Sumber data dalam penelitian ini diperoleh melalui observasi partisipatif, wawancara, dan studi dokumentasi. Instrumen utamanya adalah peneliti sendiri untuk menetapkan fokus penelitian, memilih informan sebagai sumber data, melakukan pengumpulan data, menilai kualitas data, analisis data, menafsirkan data dan membuat kesimpulan atas temuannya. Instrumen pendukung adalah pedoman wawancara, pedoman observasi dan field note (catatan lapangan).

Penelitian ini merupakan kajian sosiologis mikro dengan mengamati pengembangan kinerja guru melalui PTK pada SMA Negeri di Kota Palopo. Data yang terkumpul dianalisis secara kualitatif dengan menggunakan pendekatan logika induktif, dimana silogisme dibangun berdasarkan pada hal-hal khusus atau data di lapangan dan bermuara pada kesimpulan-kesimpulan umum. Strategi analisis data seperti dikemukakan di atas digunakan untuk memahami, mengkaji, dan menganalisis pelaksanaan pengembangan kinerja guru melalui PTK pada SMA Negeri di Kota Palopo. Proses pengelolaan dan analisis data dalam penelitian ini dilakukan sejak sebelum memasuki lapangan, selama di lapangan, dan setelah selesai di lapangan. 


\section{HASIL PENELITIAN DAN PEMBAHASAN}

Penelitian ini berusaha mengungkap pengembangan kinerja guru melalui Penelitian Tindakan Kelas (PTK) pada SMA Negeri di Kota Palopo. Temuan-temuan yang diperoleh dalam penelitian ini dikelompokkan ke dalam dua bagian, yaitu: (1) Pelaksanaan pengembangan kinerja guru melalui PTK pada SMA Negeri di Kota Palopo; dan (2) Hambatan dalam pelaksanaan pengembangan kinerja guru melalui PTK pada SMA Negeri di Kota Palopo.

\section{Pelaksanaan Pengembangan Kinerja Guru Melalui PTK pada SMA Negeri di Kota Palopo}

Berdasarkan data dari hasil observasi, wawancara, dan studi dokumentasi, peneliti menemukan bahwa pengembangan kinerja guru melalui Penelitian Tindakan Kelas (PTK) pada SMA Negeri di Kota Palopo belum sesuai harapan. PTK yang sejatinya dijadikan wahana pemecahan masalah pembelajaran dan pencarian model pembelajaran inovatif, ternyata belum terwujud. Sebahagian besar guru melaksanakan PTK hanya sekedar untuk memenuhi salah satu persyaratan kenaikan pangkat/jabatan guru. Itupun pada umumnya tidak terdokumentasi dengan baik. Laporan hasil penelitian tindakan kelas seorang guru tertentu tidak dibaca oleh guru lain, di samping karena tidak terdokumentasi di perpustakaan sekolah, juga dicetak sebanyak kebutuhan sebagai lampiran Daftar Usul Penilaian Angka Kredit (DUPAK).

Berdasarkan data hasil observasi, dokumentasi, dan wawancara dengan sejumlah guru pada SMA Negeri di Kota Palopo, ditemukan bahwa pelaksanaan penelitian tindakan kelas pada SMA Negeri di Kota Palopo belum dijadikan sarana pengembangan kinerja guru, khususnya penemuan model pembelajaran inovatif untuk peningkatan mutu pendidikan. Sebahagian guru melaksanakan PTK namun tidak rutin dan laporan hasil PTK tidak didokumentasikan di perpustakaan sekolah. Sebahagian guru lainnya belum melaksanakan PTK. Pada umumnya guru yang melaksanakan PTK bukan diawali dari upaya menemukan solusi masalah pembelajaran yang dihadapi, tetapi sebagai kelengkapan bahan persyaratan kenaikan pangkat. Pelaksanaan pengembangan kinerja guru melalui PTK pada SMA Negeri di Kota Palopo belum optimal. Pelaksanaan PTK pada SMA Negeri di Kota Palopo sebagai wahana pemecahan masalah pembelajaran dan pencarian model pembelajaran inovatif belum dimanfaatkan sebaik-baiknya oleh pihak sekolah.

Sebetulnya, pengembangan kinerja guru melalui PTK memberi keuntungan bagi individu pendidik dan lembaga sekolah. Melalui pengembangan kinerja guru melalui PTK, para pendidik dapat menyumbangkan gagasan dan inisiatif terbaiknya bagi pengembangan kinerjanya sekaligus mendukung pengembangan kinerja sekolah dengan perasaan senang, kreatif, inovatif serta bertindak secara bertanggung jawab. Selain itu, melalui pengembangan kinerja guru melalui PTK, para pendidik dilibatkan dalam upaya meningkatkan mutu kinerjanya.

Melalui kegiatan penelitian tindakan (action research) atau pada jenjang pendidikan dasar dan menengah lebih dikenal dengan Penelitian Tindakan Kelas (PTK) 
memungkinkan individu pendidik terlibat dalam mendukung pengembangan sekolah dan sekaligus pengembangan individu pendidik itu sendiri. Berbagai definisi telah dikemukakan oleh para ahli tentang penelitian tindakan. Bodgan \& Biklen mengemukakan bahwa penelitian tindakan merupakan pengumpulan informasi yang sistematik yang dirancang untuk menghasilkan perubahan sosial. Pandangan senada dikemukan oleh Burns bahwa penelitian tindakan merupakan penerapan penemuan fakta pada pemecahan masalah dalam situasi sosial dengan pandangan untuk meningkatkan kualitas tindakan yang dilakukan di dalamnya yang melibatkan kolaborasi dan kerja sama para peneliti, praktisi, dan orang awam. Pandangan yang tidak jauh berbeda dikemukakan oleh Wallace bahwa penelitian tindakan dilakukan dengan mengumpulkan data secara sistematik tentang praktik keseharian dan menganalisisnya untuk dapat membuat keputusan-keputusan tentang praktik yang seharusnya dilakukan di masa mendatang. ${ }^{19}$ Penelitian tindakan berkaitan dengan praktik di lapangan yang dilakukan oleh peneliti selaku pelaku praktik dan pengguna langsung hasil penelitiannya. Pada jenjang pendidikan dasar dan menengah penelitian yang dilakukan oleh pendidik untuk mencermati aktivitas pembelajaran yang merupakan tugas kesehariannya atau mencoba penerapan suatu model pembelajaran, biasa disebut Penelitian Tindakan Kelas (PTK).

Grubdy dan Kemmis mengemukakan bahwa penelitian tindakan bertujuan untuk mencapai tiga hal, yaitu: (a) peningkatan praktik; (b) pengembangan professional atau peningkatan pemahaman praktik oleh praktisinya; dan (c) peningkatan situasi tempat pelaksanaan praktik. Cohen dan Manion mengemukakan lima fungsi penelitian tindakan, yaitu: (a) sebagai alat untuk mengatasi masalah-masalah yang diagnosis dalam situasi spesifik atau untuk meningkatkan keadaan tertentu dengan cara tertentu; (b) sebagai alat pelatihan dalam jabatan, membekali pendidik dengan keterampilan dan metode baru dan mendorong timbulnya kesadaran diri; (c) sebagai alat untuk memasukkan pendekatan tambahan atau inovatif terhadap pengajaran dan pembelajaran ke dalam sistem yang dalam keadaan normal menghambat inovasi dan perubahan; (d) sebagai alat untuk meningkatkan komunikasi yang biasanya buruk antara pendidik dan peneliti; dan (e) sebagai alat untuk menyediakan alternatif bagi pendekatan yang subjektif, impressionistik terhadap pemecahan masalah kelas. ${ }^{20}$

Terdapat empat aspek pokok penelitian tindakan, yaitu menyusun rencana, bertindak, mengamati, dan melakukan refleksi serta merumuskan kembali rencana rencana berdasarkan informasi yang lebih lengkap dan lebih kritis. ${ }^{21}$ Penyusunan rencana dilakukan oleh peneliti dan kolaboratornya berdasarkan kesepakatan terhadap pencermatan data awal dengan mengidentifikasi masalah-masalah yang ada, menentukan tindakan untuk mengatasinya, serta menyusun rencana tindakan yang akan menuntun pelaksanaan tindakannya. Tindakan merupakan variasi praktik yang cermat, bijaksana, dan mengandung inovasi, serta digunakan sebagai pijakan bagi pengembangan tindakan-tindakan berikutnya. Pengamatan atau observasi berfungsi untuk mendokumentasikan: proses tindakan, pengaruh tindakan, keadaan dan kendala tindakan, dan masalah yang timbul dalam proses tindakan. Refleksi merupakan 
upaya memahami proses, pengaruh, kendala, dan masalah tindakan, dilakukan melalui diskusi untuk menghasilkan rekonstruksi makna situasi sosial yang diteliti dan menjadi dasar perbaikan rencana.

Empat aspek pokok penelitian tindakan tersebut di atas merupakan proses dasar penelitian tindakan yang dilakukan berulang (siklus) sampai peneliti mencapai tujuan penelitian. Proses atau siklus penelitian tindakan dapat digambarkan sebagai berikut:

Gambar Proses/Siklus Penelitian Tindakan

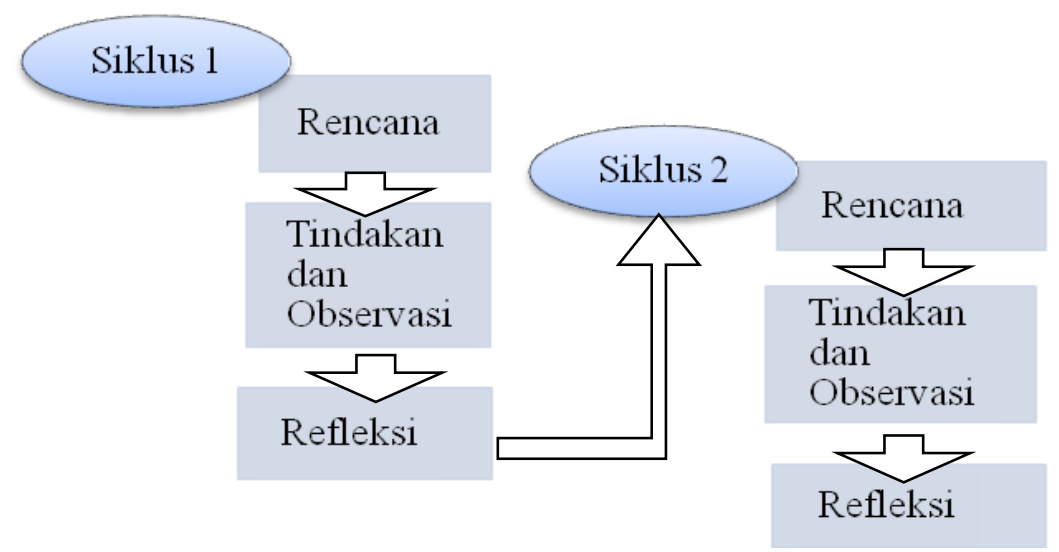

Gambar di atas menunjukkan bahwa proses penelitian tindakan pada siklus 1 dimulai dari tahap penyusunan rencana tindakan didasarkan pada pencermatan awal. Tahap berikutnya adalah melaksanakan tindakan dan observasi yang berlangsung bersamaan. Tahap refleksi dilaksanakan setelah melaksanakan tindakan dan observasi. Hasil diskusi tahap refleksi pada siklus 1 dijadikan dasar perbaikan rencana pada siklus 2. Proses tindakan pada siklus 2 mengikuti tahapan pada siklus 1, yaitu: rencana, tindakan dan observasi, serta refleksi. Siklus 3 dan seterusnya dapat dilaksanakan jika diskusi pada tahap refleksi siklus sebelumnya menyimpulkan perlunya tindakan dilanjutkan pada siklus berikutmya.

\section{Hambatan dalam Pelaksanaan Pengembangan Kinerja Guru Melalui PTK pada SMA Negeri di Kota Palopo}

Berdasarkan data hasil observasi, dokumentasi, dan wawancara dengan sejumlah guru pada SMA Negeri di Kota Palopo, ditemukan bahwa pelaksanaan pengembangan kinerja guru melalui PTK pada SMA Negeri di Kota Palopo belum optimal. Pelaksanaan PTK pada SMA Negeri di Kota Palopo sebagai wahana pemecahan masalah pembelajaran dan pencarian model pembelajaran inovatif belum dimanfaatkan sebaik-baiknya oleh pihak sekolah. Sebahagian besar guru melaksanakan PTK hanya sekedar untuk memenuhi salah satu persyaratan kenaikan pangkat dan tidak terdokumentasi dengan baik. Kendala yang mereka hadapi adalah keterbatasan waktu, dana, sumber referensi kurang, lingkungan tidak kondusif, dan motivasi kurang. Selain 
itu, sebagian guru juga masih mengalami kesulitan dalam melakukan dan menyusun laporan hasil PTK.

Sebenarnya, hambatan keterbatasan waktu karena sibuk mengajar yang dijadikan alasan sehingga tidak rutin melaksanakan PTK tidak logis karena PTK dilaksanakan dalam proses pembelajaran. Ketidakmampuan dalam menyusun laporan penelitian dan kelangkaan jurnal pendidikan yang menampung tulisan laporan hasil penelitian penting dicarikan solusi oleh para guru, kepala sekolah dan stakeholder pendidikan di Kota Palopo. Tantangan yang sering kali dihadapi dalam pengembangan kinerja guru melalui PTK) adalah adanya resistensi baik dari pihak kepala sekolah maupun dari pihak tenaga pendidik. Hal ini terjadi karena adanya perasaan khawatir karena kegiatan tersebut belum pernah dilakukan sebelumnya atau sudah pernah melakukannya dan hasilnya tidak sesuai dengan harapan. Akibatnya, muncul pandangan bahwa mereka tidak memiliki kemampuan (pengetahuan, keterampilan, dana, waktu) untuk melakukannya. Selain itu, keengganan juga muncul karena pandangan bahwa aktivitas pengembangan kinerja guru yang dilaksanakan selama ini sudah cukup memadai sehingga tidak perlu berubah untuk sesuatu yang dalam pandangan mereka belum tentu berhasil. Untuk itu, pengembangan kinerja guru melalui PTK membutuhkan kepemimpinan (superleadership) kepala sekolah, komitmen untuk mau berubah, integritas, dan keinginan kuat untuk mau terus belajar (learning school).

Jika merujuk kepada teori kinerja Gibson maka kelompok variabel yang menjadi kendala pelaksanaan PTK pada SMA Negeri di Kota Palopo adalah:

\section{Variabel Individu}

Sebagian besar guru pada SMA Negeri di Kota Palopo memiliki kompetensi yang masih minim dalam melakukan penelitian tindakan kelas. Hal tersebut disebabkan oleh masih minimnya pengetahuan (knowledge) dan unjuk kerja (skill) guru tentang PTK akibat minimnya sosialisasi dan workshop PTK. Sikap individu (selfconcept) guru juga perlu dipertanyakan yang mempermasalahkan keterbatasan waktu dan dana. Padahal, PTK itu dapat dilaksanakan seiring pelaksanaan kegiatan pembelajaran di kelas. Dari aspek niat dasar (motives), yang mendorong guru melakukan PTK adalah untuk memenuhi salah satu persyaratan sebagai kelengkapan bahan usul kenaikan pangkat, bukan atas dorongan untuk memecahkan masalah-masalah pembelajaran atau untuk menemukan model pembelajaran inovatif;

\section{Variabel Psikologis}

Masih ada sebahagian guru yang mempersepsikan kegiatan PTK merupakan kegiatan ilmiah yang hanya tepat dilakukan oleh para peneliti dan kalangan ilmuan. Sebahagian yang lain, biasanya yang masih muda, menganggap kegiatan PTK belum waktunya dilakukan karena belum wajib melakukan kegiatan pengembangan profesi. Yang sudah tua berpikir bahwa mereka sudah tidak memiliki kemampuan dan waktu untuk belajar, apalagi untuk melakukan kegiatan PTK; 


\section{Variabel Organisasi}

Sebetulnya, SMA Negeri di Kota Palopo memiliki banyak SDM guru memiliki potensi kemampuan yang dapat dikembangkan. Masalahnya, belum ada program workshop yang dirancang baik untuk mampu memotivasi guru melaksanakan PTK. Struktur organisasi sekolah dan kepemimpinan kepala sekolah juga belum memberi ruang terhadap hadirnya kreativitas dan inovasi pembelajaran. Padahal, aspek kepemimpinan kepala sekolah, desain program dan pembentukan iklim yang kondusif untuk memotivasi para guru melaksanakan kegiatan PTK perlu diwujudkan menuju sekolah kreatif dan inovatif di Era Global ini.

Teori motivasi Hersey et.al. dapat digunakan untuk menganalisis hambatan pelaksanaan pengembangan kinerja guru melalui PTK di sekolah. Hersey et.al. sebagaimana dikutip Kadarisman dalam Manajemen Pengembangan Sumber Daya Manusia, mengemukakan bahwa motivasi bergantung pada motif orang. Motif kadang-kadang didefinisikan sebagai kebutuhan, keinginan, dan gerak hati individu. Berdasarkan hasil wawancara ditemukan data bahwa ada sejumlah guru yang mengalami kesulitan memilih media dan metode yang tepat dalam pengelolaan kelas. Kesulitan yang dihadapi guru tersebut membutuhkan wadah dan tempat pemecahan masalah pembelajaran yang dialami di kelas. Selama ini para guru pada SMA Negeri di kota Palopo mencari solusi pemecahan masalah pembelajarannya dengan diskusi lepas, sharing informasi dengan sejawat dengan memanfaatkan waktu luang di sela-sela jam istirahat. Situasi ini menunjukkan kuatnya motif yang dimulai dengan adanya kebutuhan (Needs) untuk berbagi dan menemukan solusi dari kesulitan yang dihadapi. Kebutuhan untuk berbagi dan menemukan solusi ini melahirkan dorongan untuk memenuhi keinginan (Wants) untuk bisa memecahkan masalah pembelajaran agar bisa tampil lebih baik sesuai harapan. Keinginan yang kuat untuk memecahkan masalahnya melahirkan gerak hati (impulses) yang kuat untuk berkumpul, bekerjasama, membahas bersama permasalahan yang mereka hadapi. Pada titik ini peneliti meyakini bahwa para guru pada SMA Negeri di kota Palopo pada dasarnya membutuhkan wadah berbagi informasi dan memecahkan masalah pembelajaran mereka. Salah satu wadah dimaksud adalah pengembangan kinerja guru melalui PTK.

Teori Motivasi Clelland, sebagaimana dikutip M. Kadarisman dalam Manajemen Pengembangan Sumber Daya Manusia, menyatakan bahwa pekerja memiliki cadangan energi potensial yang dapat dimanfaatkan tergantung pada dorongan motivasi, situasi, dan peluang yang ada. Energi potensial tersebut akan dimanfaatkan para guru dalam kelompoknya karena didorong oleh kekuatan motif dan kebutuhan dasar harapan keberhasilan dalam mewujudkan pembelajaran yang bermutu. PTK, sebenarnya, dapat dimanfaatkan oleh guru dengan bantuan dan dorongan kepala sekolah untuk menggali potensi guru untuk menampilkan kinerjanya semaksimal mungkin. Melalui PTK para guru diberi kesempatan meningkatkan kemampuan dan kompetensinya untuk memberikan prestasi terbaik bagi sekolah tempatnya mengabdi. Tugas Kepala sekolah adalah memahami kebutuhan para guru, kemudian mem- 
berikan dorongan motivasi, memberi ruang yang cukup dan suasana kondusif untuk berprestasi.

Kebutuhan akan dorongan motivasi dan suasana kondusif untuk mewujudkan pembelajaran bermutu membutuhkan kepemimpinan kepala sekolah yang superleader. Veithzal Rivai dan Deddy Mulyadi dalam Kepemimpinan dan Perilaku Organisasi mengemukakan bahwa superleader adalah pemimpin yang mampu memimpin orang lain untuk memimpin diri sendiri. Superleader memungkinkan esensi semua kontrol atas kinerja guru adalah teristimewa pada kompetensi dan potensi guru itu sendiri, mendorong SDM guru untuk berinisiatif, bertanggungjawab sendiri, percaya diri, merencanakan tujuan sendiri, berpikir secara positif, dan mampu mengatasi permasalahan. Superleader memberi semangat kepada orang lain untuk bertanggungjawab daripada memberi perintah. Superleader fokus pada strategi pemberdayaan melalui peningkatan keterampilan, pengetahuan, dan keyakinan akan kemampuan dan potensi guru yang dipimpinnya.

Pengembangan kinerja guru melalui PTK membutuhkan kepemimpinan kepala sekolah yang memiliki kemampuan mengembangkan setiap guru menjadi self-leader. Guru yang self leader adalah guru yang memiliki pola pikir, perilaku dan tanggungjawab mengatasi tantangan yang dibebankan kepadanya, inisiatif, kreatif, inovatif, dan mampu memimpin diri mereka sendiri. Kepala sekolah yang mampu mendesain, menetapkan sistem, memengaruhi, dan membentuk guru menjadi self-leader adalah superleader. Mengembangkan setiap guru menjadi self-leader yang efektif adalah tantangan yang menarik dan berat. Kepala sekolah ditantang untuk mampu memimpin dan memberi motivasi kepada para guru yang dipimpinnya untuk mentransfer tanggungjawab yang dibebankan kepadanya sekaligus memimpin diri mereka sendiri dalam melaksanakan tanggungjawab itu. Kekuatan kepala sekolah sebagai Superleader dapat ditunjukkan pada kemampuannya menimbulkan komitmen pada para guru yang dipimpinnya terhadap visinya dan meyakini bahwa mereka adalah umat terbaik, sebagaimana firman Allah swt. dalam QS Ali 'Imran/3: 110, sebagai berikut:

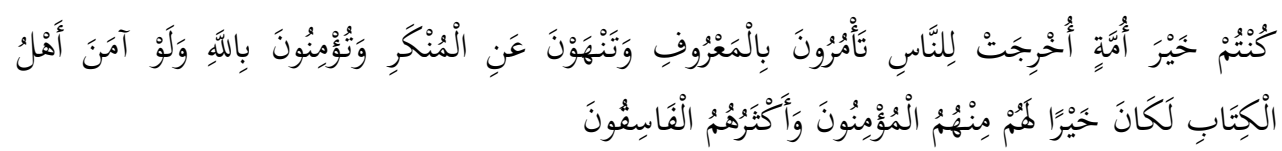

Kamu (umat Islam) adalah umat terbaik yang dilahirkan untuk manusia, (karena kamu) menyuruh (berbuat) yang ma'ruf, dan mencegah dari yang mungkar, dan beriman kepada Allah. Sekiranya Ahli Kitab beriman, tentulah itu lebih baik bagi mereka. Di antara mereka ada yang beriman, namun kebanyakan mereka adalah orang-orang fasik. ${ }^{22}$

Untuk mendorong para guru menjadi self-leader, keteladanan Rasulullah saw. patut dijadikan inspirasi para kepala sekolah. Sifat Rasulullah yang menginspirasi ini dapat dibaca dalam QS al-Ah\}zab/33: 21, sebagai berikut:

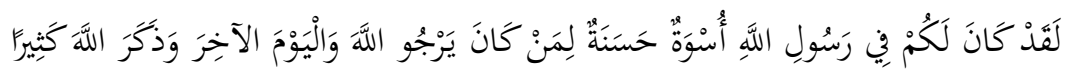


Sesungguhnya telah ada pada (diri) Rasulullah itu suri teladan yang baik bagimu (yaitu) bagi orang yang mengharap (rahmat) Allah dan (kedatangan) hari kiamat dan dia banyak menyebut Allah. ${ }^{23}$

\section{SIMPULAN}

Berdasarkan hasil penelitian yang telah dikemukakan sebelumnya maka dapat disimpulkan hal-hal sebagai berikut:

Pelaksanaan pengembangan kinerja guru melalui PTK pada SMA Negeri di Kota Palopo belum berjalan optimal dan baru sebatas memenuhi kebutuhan persyaratan kenaikan pangkat. Potensi guru belum dimanfaatkan melalui pemberdayaan, khususnya penelitian tindakan kelas. Hambatan dalam pelaksanaan pengembangan kinerja guru melalui PTK pada SMA Negeri di Kota Palopo adalah keterbatasan waktu, dana, sumber referensi kurang, lingkungan tidak kondusif, dan motivasi kurang. Selain itu, sebagian guru juga masih mengalami kesulitan dalam melakukan dan menyusun laporan hasil PTK.

\section{CATATAN AKHIR:}

1. Lihat Supardi, Kinerja Guru, Ed. 1 (Cet.1; Jakarta: Rajawali Pers, 2013), h. 7.

2. John M. Echols dan Hassan Shadily, Kamus Inggeris-Indonesia (Cet.XXVII; Jakarta: P.T Gramedia, 2003), h. 425.

3. Wibowo, Manajemen Kinerja, Ed. III (Cet. V; Jakarta: PT. RajaGrafindo Persada, 2011), h. 2.

4. Uhar Suharsaputra, Administrasi Pendidikan (Cet, I; Bandung: PT. Refika Aditama, 2010), h. 145.

5. Wibowo, Manajemen Kinerja, 2011, h. 86-88.

6. Lihat Wibowo, Manajemen Kinerja, 2011, h. 89-90.

7. Supardi, Kinerja Guru, 2013, h. 19-23, dan 25.

8. Direktorat Tenaga Kependidikan, Penilaian Kinerja Guru (Jakarta: Direktorat Jenderal Peningkatan Mutu Pendidik dan Tenaga Kependidikan Departemen Pendidikan Nasional, 2008), h. 22.

9. Uhar Suharsaputra, Administrasi Pendidikan, 2010, h. 137.

10. E. Mulyasa, Menjadi Kepala Sekolah Profesional: Dalam Konteks Menyukseskan MBS dan KBK (Bandung: PT. Remaja Rosdakarya, 2004), h. 37.

11. Veithzal Rivai dan Deddy Mulyadi, Kepemimpinan dan Perilaku Organisasi, ed. 3 (Cet. 9; Jakarta: Rajawali Pers, 2012), h. 58-61.

12. Wibowo, Manajemen Kinerja, 2011, h. 11-12.

13. Mondy R. Wayne dan Robert M. Noe, Human Resources Management (New Jersey: Pearson Prentice Hall, 2005), h. 202.

14. Lihat Veithzal Rivai, Islamic Human Capital Dari Teori ke Praktik Manajemen Sumber Daya Islami. Ed.1 (Cet.1; Jakarta: Rajawali Pers, 2009), h. 298.

15. Noe dkk., Human Resource Management: Gaining A Competitive Advantage, terj. David Wijaya, $6^{\text {th }}$ ed. (Jakarta Selatan: Salemba Empat, 2011), h. 523.

16. Tim Penyusun Kamus Pembinaan dan pengembangan Bahasa, Kamus Besar Bahasa Indonesia, Ed. 2 (Cet.9; Jakarta: Balai Pustaka, 1997), h. 503.

17. Sedarmayanti, Membangun dan Mengembangkan Kepemimpinan serta Meningkatkan Kinerja untuk Meraih Keberhasilan (Cet. I; Bandung: PT. Refika Aditama, 2011), h. 202. 
18. Wibowo, Manajemen Kinerja, h. 414-416.

19. Suwarsih Madya, Penelitian Tindakan (Action Research), Teori dan Praktik (Cet. 4; Bandung: Alfabeta, 2011), h. 9.

20. Suwarsih Madya, Penelitian Tindakan (Action Research), Teori dan Praktik, 2011, h. 25-26.

21. Suwarsih Madya, Penelitian Tindakan (Action Research), Teori dan Praktik, 2011, h. 58-63.

22. Departemen Agama R.I, Al-Qur'an dan Terjemahnya, h. 94.

23. Departemen Agama R.I, Al-Qur'an dan Terjemahnya, h. 670.

\section{DAFTAR PUSTAKA}

Al-Quran al-Karim.

Allmon, Barbara dan Sara Freeman. Menjadi Guru Kreatif. Yogyakarta: Golden Book, 2010.

Anonim. Manajemen Berbasis Sekolah. Jakarta: Depdiknas, 2007.

Appelo, Jurgen. Management 3.0: Memimpin Pengembang Agile, Mengembangkan Pemimpin yang Tangkas, Lincah, dan Gesit. Penerjemah Ati Cahayani. Jakarta: PT. Indeks, 2013.

Arikunto, Suharsimi. Dasar-Dasar Supervisi. Buku Pegangan Kuliah. Jakarta: Rineka Cipta, 2004.

Arikunto, Suharsimi, Suhardjono, dan Supardi. Penelitian Tindakan Kelas. Cet. X; Jakarta: PT. Bumi Aksara, 2011.

Amstrong, Michael. Performance Management. Alih bahasa Tony Setiawan. Yogyakarta: Tugu, 2004.

Armstrong, Thomas. Sekolah Para Juara. Bandung: Kaifa, 2002.

Armstrong, Thomas. The Best School. Bandung: Kaifa, 2006.

Arniati PH dan Deni Hadiana. Pemanfaatan Hasil Ujian Nasional Untuk Peningkatan Mutu Pendidikan. Jakarta: Puspendik, 2008.

Bacal, Robert. Performance Management, terj. Surya Darma. Jakarta: Gramedia, 2001.

Bacal, Robert. How to Manage Performance. New York: McGraw-Hill Companies, inc., 2004.

Barclay, I., Dann, Z., and Holroyd, P. New Product Development a Practical Workbook for Improving Performance. Oxford: Butterworth Heinemann, 2000.

Bell, Julie. Performance Intelligence at Work. New York: McGraw-Hill Companies, inc., 2009.

Bono, Edward de. New Thinking for the New Millenium. Jakarta: Elex Media Komputindo, 2000.

Braham, Barbara J. Creating A Learning Organization, terj. Zalzulifa. Jakarta: Elex Media Komputindo, 2003.

Bungin, Burhan. Sosiologi Komunikasi: Teori, Paradigma, dan Diskursus Teknologi Komunikasi di Masyarakat, ed. 1. Cet. 4; Jakarta: Kencana, 2009.

Bungin, Burhan. Penelitian Kualitatif: Komunikasi, Ekonomi, Kebijakan Publik. Dan Ilmu Sosial Lainnya, ed. 1. Cet. 4; Jakarta: Kencana Prenada Media Group, 2010.

Bush, T., L. Bell \& D. Middlewood. The Principles of Educational Leadership. Second Edition. London: A Sage Publications Company, 2010.

Cascio, Wayne F. Managing Human Resource. New York: McGraw Hill, 2006.

Ciptono dan Ganjar Triadi. Guru Luar Biasa. Yogyakarta: Bentang, 2009.

Collins, J. Good to Great. New York: Harper Collins, 2001.

Covey, Stephen R. The Leader in Me. Jakarta: Gramedia, 2008.

Daft, Richard L. Era Baru Manajemen (New Era of Management), Buku 2, Ed. 9. Penerjemah Tita Maria Kanita, Jakarta: Salemba Empat, 2011.

Danim, Sudarwan. Inovasi Pendidikan dalam Upaya Peningkatan Profesionalisme Tenaga Kependidikan. Bandung: Pustaka Setia, 2002. 
Departemen Agama Republik Indonesia. Al-Qur'an dan Terjemahnya, juz 1-30. Surabaya: Mekar Surabaya, 2004.

Depdiknas, Manajemen Peningkatan Mutu Berbasis Sekolah. Buku I. Jakarta: Depdiknas, 2003.

DePorter, Bobbi. Quantum Note-Taker. Bandung: Kaifa, 2004.

DePorter, Bobbi. Quantum Thinker. Bandung: Kaifa, 2004.

DePorter, Bobbi. Quantum Learner. Bandung: Kaifa, 2004.

DePorter, Bobbi, Mark Reardon, dan Sarah Singer-Nourie. Quantum Teaching: Mempraktikkan Quantum Learning di Ruang Kelas. Bandung: Kaifa, 2009.

Dharma, Surya. Manajemen Kinerja, Falsafah, Teori dan Penerapannya. Yogyakarta: Pustaka Pelajar, 2005.

Direktorat Pendidikan Menengah Umum Dirjen Dikdasmen Depdiknas. Pedoman Pengembangan Kultur Sekolah. Jakarta: Direktorat Pendidikan Menengah Umum, 2004.

Direktorat Pembinaan Sekolah Menengah Atas Dirjen Manajemen Pendidikan Dasar dan Menengah Depdiknas. Panduan Penyelenggaraan Program Rintisan SMA Bertaraf Internasional (R-SMA-BI). Jakarta: Direktorat Pembinaan Sekolah Menengah Atas, 2009.

Direktor DePorter, Bobbi at Tenaga Kependidikan. Penilaian Kinerja Guru. Jakarta: Direktorat Jenderal Peningkatan Mutu Pendidik dan Tenaga Kependidikan Departemen Pendidikan Nasional, 2008.

Dressler, G. Human Resources Management. Nineth Edition. New Jersey: Upper Saddler River, Prentice Hall, 2003.

Engkoswara dan Aan Komariah. Administrasi Pendidikan (Bandung: Alfabeta, 2010.

Engkoswara. Paradigma Manajemen Pendidikan Menyongsong Otonomi Daerah. Bandung: Yayasan Amal Keluarga, 2001.

Fahmi, Irham. Manajemen Kinerja Teori dan Aplikasi. Cetakan Ketiga; Bandung: Alfabeta, 2013.

Fiedler, B. Strategic Management for School Development Leading Your School's Improvement Strategy. London: A Sage Publications Company, 2005.

Gill, R. Theory and Practice of Leasership. New York: A Sage Publications Company, 2009.

Godard, Alain and Vincent Lenhardt. Transformational Leadership, Shared Dreams to Succeed. London: Macmillan Publishers, 2000.

Hoon, Hum Sin. Memenangkan Persaingan Cara Cheng Ho Seni Kolaborasi, Kepemimpinan, Pengelolaan SDM dan Logistik, serta Warisan Iman Sang Laksamana Agung. Terj. Djohan Diaz Tjahjadi. Jakarta: PT. Kompas Media Nusantara, 2012.

Hughes, R.L., R.C. Ginnet \& G.J. Curphy. Leadership Enhancing the Lesson of Experience. New York: McGraw Hill.

Hunsanker, P.L. Training in Management Skill. Upper Saddle River, New Jersey: Prantice Hall, 2002.

Hussey, D.E. How to Manage Organisational Change. London: Kogan Page Limited, 2000.

Iskandar. Metodologi Penelitian Pendidikan dan Sosial (Kuantitatif dan Kualitati). Cet. II; Jakarta: Gaung Persada Press, 2009.

Jensen, Eric. Guru Super \& Super Teaching, Lebih dari 1000 Strategi Praktis Pengajaran Super, terj. Benyamin Molan. Jakarta Barat: PT. Indeks Permata Puri Media, 2010.

Kadarisman, M. Manajemen Pengembangan Sumber Daya Manusia, ed. 1. Cet. 1; Jakarta: Rajawali Pers, 2012.

Kasali, Rhenald. Change. Jakarta: Gramedia Pustaka Utama, 2005.

Kirkpatrick, Donald L. Improving Employee Performance. New York: Amacom, 2006.

Lawson, Ken. Performance Review. London: Axis Publishing Limited, 2005.

Lako, A. Kepemimpinan dan Kinerja Organisasi (Isu, Teori, dan Solusi). Yogyakarta: Amara Books, 2004. 
Maddux, Robert B. Effective Performance Appraisals. California: Crisp Publication, Inc., 2000.

Madya, Suwarsih, Penelitian Tindakan (Action Research), Teori dan Praktik. Cet. 4; Bandung: Alfabeta, 2011.

Manz, Charles C. and Henry P Sims Jr. The Superleadership Learning Others to Lead Themseves. San Fransisco: Berrett-Koehler Publishers, Inc. 2001.

Moleong, Lexy J. Metodologi Penelitian Kualitatif, edisi revisi. Cet. 30; Bandung: PT. Remaja Rosdakarya, 2011.

Muhadjir, Noeng. Metodologi Penelitian Kualitatif. Yogyakarta: Rake Sarasin, 1994.

Mulyasa, E. Menjadi Kepala Sekolah Profesional: Dalam Konteks Menyukseskan MBS dan KBK. Bandung: PT. Remaja Rosdakarya, 2004.

Neal, James E. Jr. Guide to Performance Appraisals. Ohio: Neal Publication, Inc., 2001.

Noe, Raymond A, John R. Hollenbeck, Barry Gerhart, Patrick M. Wright. Human Resource Management: Gaining A Competitive Advantage, terj. David Wijaya, $6^{\text {th }}$ ed. Jakarta Selatan: Salemba Empat, 2011.

Pardong, A. Tugas Pokok dan Fungsi Pengawas. Jakarta: Badan Diklat Depdiknas, 2003.

Parkay, F.W \& G.J. Hass \& E.J. Ancil. Curruculum Leadership Reading for Developing Quality Educational Program. Nineth Edition. New York: Pearson. 2010.

Republik Indonesia. Peraturan Pemerintah R.I. Nomor 19 Tahun 2005 Tentang Standar Nasional Pendidikan.

Republik Indonesia. Peraturan Pemerintah R.I. Nomor 19 Tahun 2007 Tentang Standar Pengelolaan Sekolah/Madrasah.

Republik Indonesia. Undang-Undang Nomor 20 Tahun 2003 tentang Sistem Pendidikan Nasional.

Republik Indonesia. Undang-Undang R.I. Nomor 14 Tahun 2005 tentang Guru dan Dosen.

Rivai, Veithzal, Deddy Mulyadi. Kepemimpinan dan Perilaku Organisasi, ed. 3. Cet. 9; Jakarta: Rajawali Pers, 2012.

Rivai, Veithzal. Islamic Human Capital Dari Teori ke Praktik Manajemen Sumber Daya Islami. Ed.1, Cet.1; Jakarta: Rajawali Pers, 2009.

Robbins, Stephen P., Coulter, Mary. Management. Tenth Edition, Terj. Bob Sabran dan Devri Burnadi Putera. Jakarta: Penerbit Erlangga, 2010.

Rusman. Model-model Pembelajaran: Mengembangkan Profesionalisme Guru, ed. 1. Cet. 1; Jakarta: Rajawali Pers, 2010.

Sedarmayanti. Membangun dan Mengembangkan Kepemimpinan serta Meningkatkan Kinerja untuk Meraih Keberhasilan. Cet. I; Bandung: PT. Refika Aditama, 2011.

Smith, Jane. Empowering People. London: Kogan Page Limited, 2000.

Stuart-Kottze, Robin. Performance. London: Prentice Hall, 2006.

Sugiyono. Metode Penelitian Bisnis. Cet. X; Bandung: Alfabeta, 2007.

Sugiyono. Metode Penelitian Pendidikan, Pendekatan Kuantitatif, Kualitatif. Cet. V; Jakarta: Alfabeta, 2008.

Sugiyono. Memahami Penelitian Kualitatif. Bandung: Alfabeta, 2012.

Suharsaputra, Uhar. Administrasi Pendidikan. Cet, I; Bandung: PT. Refika Aditama, 2010.

Suhardan, Dadang. Supervisi Profesional, Layanan dalam Meningkatkan Mutu Pengajaran di Era Otonomi Daerah. Cet. 3; Bandung: Alfabeta, 2010.

Supardi. Kinerja Guru. Ed. 1, Cet. 1; Jakarta: Rajawali Pers, 2013.

Supriadi, Dedi. Mengangkat Citra dan Martabat Guru. Cet. 1; Yogyakarta: Adicita Karya Nusa, 1998.

Susanto, A. B. dan R. Masri Sareb Putra. 60 Management Gems: Applying Management Wisdom in Life. Jakarta: PT. Gramedia Pustaka Utama, 2010 
Wade, D. and Recardo, R. Coorporate Performance Management: How to Build a Better Organization Through Measurement-Driven Strategic Allignment. Oxford: ButterworthHeinemann, 2001.

Wahyudi, Kepemimpinan Kepala Sekolah dalam Organisasi Pembelajar. Cet. I; Bandung: Alfabeta, 2009.

Wibisono, Dermawan. Manajemen Kinerja Konsep, Desain, dan Teknik Meningkatkan Daya Saing Perusahaan. Jakarta: Penerbit Erlangga, 2006.

Wibowo. Manajemen Kinerja, ed. III. Cet. V; Jakarta: PT. RajaGrafindo Persada, 2011.

Wibowo. Manajemen Perubahan, ed. 3. Cet. 3; Jakarta: PT. RajaGrafindo Persada, 2011.

Wiles, J \& J. Bondi. Supervision A Guide to Practice. Second Edition. London: Charles E. Merrill Publishing Company, 2003.

Yaumi, Muhammad. "Pengembangan kinerja Guru Melalui Penerapan Kecerdasan Jamak", Disertasi Program Pascasarjana, Program Pascasarjana Universitas Negeri Jakarta, Jakarta, 2011.

Yaumi, Muhammad. Model Perbaikan Kinerja Guru dalam Pembelajaran. Makassar: Alauddin Press, 2014.

Yulk, G. Leadership in Organization. Seventeenth Edition. Upper Saddler River, New Jersey: Pearson. 2010. 